\title{
An Explanatory Study On Consumers' E-Complaints About Discount Stores In Turkey ${ }^{1}$ \\ (Research Article)
}

\author{
Türkiye'de Tüketicilerin İndirim Mă̆azalarından Şikâyetleri Üzerine \\ Açıklayıcı Bir Çalışma \\ Doi: 10.29023/alanyaakademik.885649
}

\section{Tamer BARAN}

Ögrr. Gör. Dr., Pamukkale Üniversitesi, Kale MYO

tbaran@pau.edu.tr

Orcid No: 0000-0002-8711-6561

How to cite this article: Baran, T. (2021). “An Explanatory Study On Consumers' E-Complaints About Discount Stores In Turkey” Alanya Academic Review, Vol:5, No:3, pp.1517-1531.

Keywords:

Retailing, Discount stores, Consumer behaviour, Consumer complaints, Content analysis

Received: 24.02.2021

Accepted: 27.09 .2021

\begin{abstract}
This paper aims to identify consumers' complaints and future reactions about discount stores, which is one of the growing sectors of recent years in Turkey that has one of the fastest developing economies in the world. Data were collected from the most popular online complaint forum in Turkey. A total of 921 complaints about three discount stores were examined through manual content analysis. Findings of the study showed that consumers mostly complain about the products, personnel and price \& payment of discount stores, respectively. Findings also indicated that almost one out of every 4 complaints were in foods of discount stores. Moreover, the study demonstrated that the most likely reaction of consumers as a result of their negative experiences with discount stores is boycotting. In addition, approximately one in six consumers used photographs to provide evidence of their complaints. The products of discount stores are the category of complaints that consumers use photographs most frequently.
\end{abstract}

\section{INTRODUCTION}

Understanding and evaluating consumer complaints help firms to understand what should be considered in customer satisfaction, and develop the right marketing strategies. In this respect, in recent years, many studies (Khan et al., 2019; Lee and Lee, 2020; Armstrong et al., 2021) have investigated consumer complaints using some models in the field of marketing. One of the most popular models was proposed by Day and Landon (1977). The model was expanded by some authors in time with the addition of predecessors and successors (Bearden and Teel, 1983; Singh, 1988; Huang et al., 2014), and was tested in different sectors. The study conducted by Heung and Lam (2003) was on hotel restaurant services, the study of Ro (2015) reviewed the complaints about restaurant services, another study conducted by Garín-Muñoz et al. (2016) dealt with the telecommunication sector. In addition, the study of Sampaio et al. (2018)

${ }^{1}$ This study is extended and revised version of the paper which was presented in the 6 . International Congress on Social, Human and Administrative Sciences. 
conducted on hospitality, the study of Suomi and Järvinen (2018) conducted on financial sector, the study of Wang and Alexander (2018) on food supply chain are just a few of them.

Although the model was dealt with so extensively in the literature, the issue of consumer complaints against discount stores was largely ignored. However, the discount store sector has developed significantly between 2000-2015 in the world. In this period, the market share of discount stores is ahead of all European countries with an approximately 3 -fold increase in Turkey (Jacobsen et al., 2017). In this respect, it is important that the complaints of consumers about discount stores are determined. On the other hand, studies on consumer complaints in the retailing sector (Huefner and Hunt, 1992; Harrison-Walker, 2001; Park, 2005; Lee et al, 2018) are more focused on categorizing complaints and ignored consumer reactions. Moreover, there are several studies conducted in developed markets, for instance Scotland (Broadbridge and Marshall, 1995), South Korea (Park, 2005; Lee et al., 2018) and USA (Huefner and Hunt, 1992; Harrison-Walker, 2001; Yang and Peterson, 2002). However, the number of studies regarding consumer complaints about retailers in developing markets is extremely limited.

In this context, this study aims to unveil consumers' e-complaints and future reactions about discount stores, which is one of the fastest growing sectors of the world (Jacobsen et al., 2017) in Turkey, which hosts one of the most rapidly developing economies in the world (Ant and Hacaoglu, 2018; pwc.com.au, 2017). Thus, the current study tries to answer three questions:

$R Q 1$ : Which features do consumers complain about discount stores?

$R Q 2:$ How do consumers react as a result of their dissatisfaction towards discount stores?

$R Q 3:$ Which criteria should firms consider in order to ensure higher customer satisfaction in discount retailing sector in a developing market?

In further parts of the study, discount stores and their characteristics, the Consumer Complaint Behaviour (CCB) model mentioned in the literature will be discussed, the methodology of the study will be clarified, the findings of the study will be explained in detail, and the study will be terminated with the results and discussion parts.

\section{LITERATURE REVIEW}

\subsection{Discount Stores And Their Characteristics}

Although discount stores seem to largely implement supermarket strategies, they constitute a retailer class that offers products or services to consumers at a low price through keeping operational costs as low as possible (Levy and Weitz, 2012). The cost advantage plays a vital role in rising market share of retailers by allowing them to offer products at a lower price to consumers (Park, 2005). Discounters practice some strategies to achieve this cost advantage (Bardakci and Baran, 2019). The low price that they offer as a result of these strategies implemented by discount stores, on the one hand, helps them to increase their market shares (Jacobsen et al., 2017), and also, brings some concerns on consumers.

Findings (Ailawadi et al, 2001; Baran, 2019; Baran, 2021; Juhl et al, 2006) show that consumers' perceived quality towards private-labelled products is lower than in nationalbranded products because of their price. Some findings (Orel and Kara, 2014) show that service quality is a strong variable which has an effect on consumer satisfaction. Although discounters operate with less staff to decrease operational costs, Major (2018) reported that consumers' evaluations on the service quality of discount stores are low. The store atmosphere is a crucial 
issue for retailers. In fact, Kotler (1973) emphasized that the store atmosphere is sometimes as important as the basic products of retailers. Discounters design a simple store atmosphere and often display products inside the package to reduce their operational costs. However, the instore design created by discount stores in this way reasons negatively with the consideration of consumers. In Major's (2018) report, ALDI was ranked in the twenty-fourth and Walmart brought up the rear on consumers' atmosphere evaluation among thirty retailers. Finally, discounters offer consumers limited kind of products compared to other retailers, and a result of this, they purchase a higher amount of this limited kind of goods from their suppliers and aim to gain a cost advantage by increasing their bargaining power. At this point, Kahn (1998) and Chowdhury et al. (2014) found that the variety of products in the retail store affected consumer satisfaction.

\subsection{Consumer Complaint Behaviour Theory}

Consumer dissatisfaction is the result of negative experiences about the product purchased or about the service that does not cover the expectations related to them (Day, 1984). The reactions of consumers that appear as a result of these negative experiences are defined as Consumer Complaint Behaviour (CCB) (Singh, 1988). One of the most widely accepted models about CCB is the model that was proposed by Day and Landon (1977). In the model, the authors (1977) mentioned three types of CCB as a result of dissatisfaction. In this context, consumers may not react at any time, may react personally, or show their reactions at the institutional level. As it is understood from this, dissatisfaction is the main element of the CCB model.

In the CCB model that dissatisfaction is related to the consumer expectations and to the level of consumer approval for the product in question (Day and Landon, 1977). Consumers transfer their dissatisfactions, which occur as a result of the failure to cover their expectations and disapproval for the product, through different channels to their environments or institutions. Matilla and Wirtz (2004) grouped the channels used to report the complaints under four groups: face-to-face, via telephone, letter and e-mail, which were mostly used in the pre-Internet period and which had some disadvantages for consumers. The time costs of the complaints made via these channels are very high for consumers. In complaints that are made via these channels, consumers are unlikely to achieve their goals because of difficult access to individuals/institutions and low probability of affecting institutions, etc. (Day, 1984; Chebat et al., 2005). Because of these disadvantages, consumers did not complain too much when there were no online complaint channels (Chebat et al., 2005).

Developing technology presented to consumers online complaining platform as a new alternative (Istanbulluoglu et al., 2017). Making complaints by using online channels that arose with the spread of the internet is easier and more effective for consumers than in the preinternet period. In the preinternet period, consumers had to experience time-consuming situations like trying to reach by phone, waiting in the automatic telephone system, contacting companies via letter and waiting for answers. With the social networks that emerged as a result of increasing intensive internet use, they can easily create contents related with their complaints within minutes (Grégoire et al., 2015). Moreover, online channels provide access to individuals and institutions without the limitation of a specific place. Online complaint forums have much more influence power than preinternet period channels because of their easy availability for consumers (Goldenberg et al., 2001; Harrison-Walker, 2001; Kim et al., 2015; Balaji et al., 2016).

Another benefit provided by online channels in the CCB model is that it allows consumers to present evidence to support their complaints. The internet enables consumers to add photos, 
videos, etc. to the contents, which allowed them to use evidence to increase the effect of consumer complaints (Simonson and Rosen, 2015). Consumers who comment on complaints use photos to support their claims and provide evidence on some complaint pages.

Day and Landon (1977) indicates that consumers who cannot find solutions to their problems can show their reactions in different ways. One of the reactions of consumers whose complaint is not resolved is to boycott the company. Some reports (Drennan, 2011; Grant, 2013) stated that more than $80 \%$ of consumers were more likely to stop shopping from a company that did not care about customer complaints and did not try to solve them. Consumers can also react to the company by sharing their negative experiences with their environments (Blogdet, Wakefield and Barnes, 1995). Maybe, this is the most dangerous consumer response for companies because two-thirds of the consumers see online reviews as the most reliable sources following their families and friends (Nielsen, 2015). Moreover, the reviews of experienced consumers affect the purchasing behaviour of consumers at a significant level (Podnar and Javernik, 2012). Consumers can apply to companies, or private or public institutions for compensation and to show their reactions as well. Grégoire et al. (2015) mentioned that contacting the companies is the best scenario for companies because when the company eliminates the subject of complaints, it can win the consumer as well as prevent negative word of mouth. Aside from these, consumers may also react in the form of legal compensations. Right at this point, the Consumer Arbitration Panel and Consumer Courts are some of the methods firms can apply (Blodgett et al., 2018).

There are important findings unrolled in previous studies on retailing. Blodgett and Anderson (2000) expressed that customers largely complain about the products of discount stores compared to other retailers. Broadbridge and Marshall (1995) found that the most important causes of consumer dissatisfaction in the electrical goods industry were delays in the repair/exchange process and poor customer service. Harrison-Walker (2001) exposed that US consumers mostly complained about the personnel and refunding of a firm in the airline's service industry. Huefner and Hunt (1992) showed that consumers complaints on retailers were with regard to product quality, personnel, service, price \& payment and atmosphere in the USA. Lee et al. (2018) revealed that consumers' e-complaints were mostly related with payment, personnel, pricing, product, refund and return policy in the South Korean retail industry. Major (2018) reported that US consumers mostly complaint about the store atmosphere and service quality of discount stores. Park (2005) found that personnel, atmosphere and product quality respectively, were discount store features that consumers mostly complained about. Park (2005) also mentioned that consumers mostly complained about electrical goods of global discount stores and it was followed by food and groceries.

In addition to this, there are different results found in several studies about consumers' future reactions. Broadbridge and Marshall (1995) revealed that very few consumers did "no action" when they dissatisfied. Findings of the study also showed that Scottish consumers shared negative shopping experience with their families or friends, and boycotted the brand or seller in the retailing industry. Makarem and Jae (2016) found out that consumers would boycott retailers because of their poor customer service and unfair pricing.

\section{METHODOLOGY}

The present study, which was designed as a qualitative study, focused on determining the complaints and responses of consumers about discount stores. The process summarized in Figure 1 was followed in this study. In this direction, three discount stores (BIM, A101, Sok) which operate in retailing sector in Turkey were included in the study. These discount retailers 


\section{Included Stores}

BIM, A101 and Sok which have the most stores (perakendekulis.com, 2018) and are the most frequently preferred discount stores in Turkey (Twentfy, 2017)

\begin{tabular}{|c|}
\hline \multicolumn{2}{|c|}{ Platform Selection } \\
sikayetvar.com which is the most popular e-complaint forum in Turkey (Yilmaz et al.,2016) \\
\begin{tabular}{|c|c|} 
Determining the Period \\
December, 2018 (Malhotra, 2004)
\end{tabular} \\
Totally 921 e-complaints (474 A101, 262 BIM, 185 Sok) \\
Gathering Data
\end{tabular}

\section{Complaint Categorization}

Product, Repair, Return, Atmosphere, Personnel, Service, Price \& Payment, Consumeroriented, Other (Huefner and Hunt, 1992)

\begin{tabular}{|l|}
\hline Further Consumer Reaction \\
Boycott, Complaint to the Environment, Complaint to the Business, to Private or Public \\
Institutions, Applying Legal Authorities for Compensation (Day and Landon, 1977)
\end{tabular}

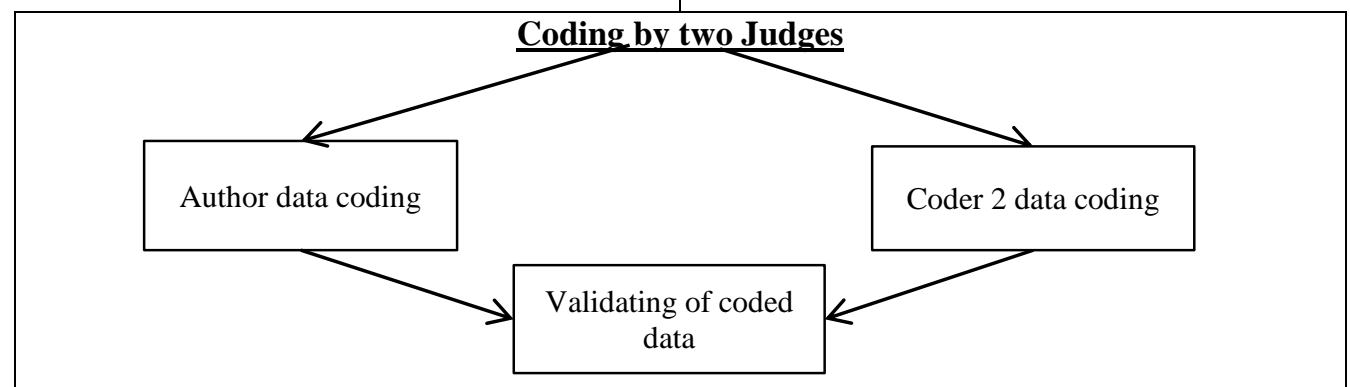

\section{Reporting and Inference}

were included in the scope of this study for two reasons. Firstly, they have the highest store numbers with totally more than 20.000 in Turkey (perakendekulis.com, 2018).

Figure1: Summarized research process of the study

Secondly, approximately $85 \%$ of consumers prefer one of these discount stores as a retailer in shopping activities (Twentify, 2017). The data were collected from sikayetvar.com, which allows consumers to share publicly-available complaints, and is the most popular complaint forum in Turkey. Gaur and Kumar (2018) expressed that in human-intensive content analysis, a relatively small sample is more efficient for scholars. In this context, consumer complaints 
which were shared between 1-31 December on the aforementioned platform were included in the scope of the study, and a total of 921 complaints were evaluated with the manual content analysis.

Content analysis, which is a widely used method in marketing research, can be defined as coding of texts according to categories defined by researchers (Lee et al., 2020; Pilny et al., 2019). Short and Palmer (2008) mentioned about three types of approaches, namely human scored system (also called as manuel content analysis), individual word-count system and computerized system, to classify content analysis in the data coding. Lee et al. (2020) indicated that the manual content analysis took more time than the other types, and was a method with a high validity level (Lee et al., 2020). Also, they mentioned that manual content analysis had a lower reliability level than the other types of content analysis. However, the reliability of content analysis largely depends on the design of the study and how loyal it is to the defined process (Gaur and Kumar, 2018). Besides Duriau et al. (2007) specified that when the researchers need to view latent content, for instance inference meaning, manual content analysis is a reliable way. In this study manual content analysis method was used by trying not to ignore any stages of the research process. This system requires manual coding by trained coders. In this points, researchers should determine coding units (for instance, word, sentence, paragraph, full text), and coding schemes, and should prepare a coding manual with descriptions and assignments of each category (Gaur and Kumar, 2018). The current study, full text was chosen as the coding unit to minimize the possibility of errors in assigning to categories. In content analysis, researchers can create their own coding schemes (Potter and Levine-Donnerstein, 1999), or they can create a coding scheme by making use of previous studies and make a categorization accordingly (Gaur and Kumar, 2018). Using previous studies help researchers accumulate a consistent mass of information when they are constructing a coding scheme (Krippendorf, 2004). For this reason, in coding, to classify the consumer complaints, Huefner and Hunt's (1992) complaint categorization approach was used. In this respect, consumer complaints were categorized and coded as: (1) product, (2) repairs, (3) return, (4) atmosphere, (5) personnel, (6) service, (7) prices and payments, (8) consumer-originated and (9) other.

Then, the reactions of consumers in further periods were evaluated in line with Day and Landon's (1977) CCB model. In this model, consumer reactions were categorized and coded as (1) boycott, (2) complaint to the environment, (3) complaint to the business, private or public institutions and (4) applying legal authorities for compensation.

After the coding scheme decision, the encoding was manually carried out by author and an independent encoder who had PhD degree in marketing. In this process, the author gave detailed information about the aim of the study, coding scheme and subject for content analysis to the independent coder, and the coding process was started.

Inter-coder reliability is another crucial issue in content analysis. Scholars can use several methods such as correlation coefficient, Cohen's kappa or Krippendorf's alpha, to test the reliability of inter-coder (Neuendorf, 2002) or ratio, which means agreements between coders relative to the total number of coding decisions (Lee et al., 2020). In this context, the correlation coefficient should not be 0.7 , Cohen's kappa should not be 0.8 , Krippendorf's alpha should not be 0.8 (Neuendorf, 2002). In the study correlation coefficient was used to test inter-coder reliability, and a high correlation coefficient was found (0.87). As the final stage of the research process, the findings were reported and inferences will be described in the next section. 


\section{FINDINGS}

The frequencies and percentages for the main categories of complaints, which were obtained as a result of the content analysis according to the stores, are given in Table 1. As can be seen in the table complaints about A101 stores account for more than half of the total complaints. The complaints of the consumers about discount stores were mainly grouped under the categories as; products, personnel, prices and payments and others (88.7\%). The complaints about the products of the discount stores account for more than $38 \%$ of the total complaints, and the complaints about other issues, complaints about personnel and complaints about prices and payments follow this. On the other hand, consumers only filed two complaints to discount stores about repairs.

Table 1: The complaint frequencies of the consumers by main complaint categories

\begin{tabular}{cccccc}
\hline $\begin{array}{c}\text { Main Complaint } \\
\text { Category }\end{array}$ & BIM & A101 & Sok & $f$ & \% \\
\hline \hline Product & 138 & 170 & 43 & 351 & $\mathbf{3 8 . 1 1}$ \\
Repair & 1 & 1 & - & 2 & $\mathbf{0 . 2 2}$ \\
Return & 1 & 17 & 29 & 47 & $\mathbf{5 . 2 1}$ \\
Atmosphere & - & 6 & 3 & 9 & $\mathbf{0 . 9 8}$ \\
Personnel & 48 & 69 & 50 & 167 & $\mathbf{1 8 . 1 3}$ \\
Service & 12 & 22 & 6 & 40 & $\mathbf{4 . 3 4}$ \\
Price \& Payment & 29 & 56 & 17 & 102 & $\mathbf{1 1 . 0 7}$ \\
Consumer-oriented & 2 & 2 & 1 & 5 & $\mathbf{0 . 5 5}$ \\
Other & 31 & 131 & 36 & 198 & $\mathbf{2 1 . 3 9}$ \\
\hline Total & $\mathbf{2 6 2}$ & $\mathbf{4 7 4}$ & $\mathbf{1 8 5}$ & $\mathbf{9 2 1}$ & $\mathbf{1 0 0 . 0 0}$ \\
\hline
\end{tabular}

In Table 2, the frequency distribution of consumer complaints is shown according to subcategories. The consumers complain about the food products of the most discount stores in these subcategories (70.37\%). However, consumers also complained about the rudeness and disrespect of the discount store personnel (45.51\%). Another point that comes to the forefront in the table is that consumers complained that the prices of the discount stores were high (25.74\%). Among other complaint issues, the highest rate belongs to the deceptive advertisements and plastic bag charges. The sub-categories of these two complaints account for approximately half of the "other" category title.

Table 2: The complaint frequencies of consumers by sub-categories

\begin{tabular}{|c|c|c|c|c|c|c|c|}
\hline \multirow{2}{*}{$\begin{array}{c}\text { Main } \\
\text { Categories }\end{array}$} & \multirow{2}{*}{ Sub-categories } & \multicolumn{3}{|c|}{ Discount stores } & \multirow{2}{*}{$f$} & \multirow{2}{*}{ Total } & \multirow{2}{*}{$\%$} \\
\hline & & BIM & A101 & Sok & & & \\
\hline \multirow{5}{*}{ Product } & Foods & 115 & 99 & 33 & 247 & & 70.37 \\
\hline & Electronic goods & 6 & 28 & 4 & 38 & & 10.83 \\
\hline & Cleaning Stuff & 5 & 3 & 1 & 9 & & 2.56 \\
\hline & Other & 12 & 40 & 5 & 57 & & 16.24 \\
\hline & Total & 138 & 170 & 43 & & 351 & \\
\hline \multirow{2}{*}{ Repair } & Repair & 1 & 1 & - & 2 & & 100.00 \\
\hline & Total & 1 & 1 & - & & 2 & \\
\hline \multirow{2}{*}{ Return } & Not Accepting Returns & 1 & 13 & 21 & 35 & & 74.47 \\
\hline & Difficulty in Returns & - & 4 & 8 & 12 & & 25.53 \\
\hline
\end{tabular}




\begin{tabular}{|c|c|c|c|c|c|c|c|}
\hline \multirow{4}{*}{ Atmosphere } & Total & 1 & 17 & 29 & & 47 & \\
\hline & Temperature in the Store & - & 4 & 3 & 7 & & 77.78 \\
\hline & Store Arrangement & - & 2 & - & 2 & & 22.22 \\
\hline & Total & - & 6 & 3 & & 9 & \\
\hline \multirow{6}{*}{ Personnel } & Disrespectful / Rude & 25 & 30 & 21 & 76 & & 45.51 \\
\hline & Insult / Hurting & 3 & 13 & 4 & 20 & & 11.98 \\
\hline & Aggressiveness & 1 & 4 & 2 & 7 & & 4.19 \\
\hline & Uninterested & 6 & 10 & 10 & 26 & & 15.57 \\
\hline & Other & 13 & 12 & 13 & 38 & & 22.75 \\
\hline & Total & 48 & 69 & 50 & & 167 & \\
\hline \multirow{5}{*}{ Service } & $\begin{array}{c}\text { Complaints about Plastic } \\
\text { Bags }\end{array}$ & 7 & 4 & 5 & 16 & & 40.00 \\
\hline & Poor / Slow Service & 4 & 10 & 1 & 15 & & 37.50 \\
\hline & $\begin{array}{c}\text { Complaints about Customer } \\
\text { Services }\end{array}$ & - & 4 & - & 4 & & 10.00 \\
\hline & Other & 1 & 4 & - & 5 & & 12.50 \\
\hline & Total & 12 & 22 & 6 & & 40 & \\
\hline \multirow{5}{*}{$\begin{array}{l}\text { Price \& } \\
\text { Payment }\end{array}$} & $\begin{array}{l}\text { Inconsistency between } \\
\text { Label and Counter }\end{array}$ & 7 & 32 & 3 & 42 & & 41.58 \\
\hline & High Prices & 19 & 5 & 2 & 26 & & 25.74 \\
\hline & Receiving More Prices & 2 & 13 & 6 & 21 & & 20.79 \\
\hline & Other & 1 & 6 & 5 & 12 & & 11.89 \\
\hline & Total & 29 & 56 & 16 & & 102 & \\
\hline \multirow{2}{*}{$\begin{array}{l}\text { Consumer- } \\
\text { oriented }\end{array}$} & $\begin{array}{l}\text { Consumer-oriented } \\
\text { Complaints }\end{array}$ & 2 & 2 & 1 & 5 & & 100.00 \\
\hline & Total & 2 & 2 & 1 & & 5 & \\
\hline \multirow{6}{*}{ Other } & Deceiving Advertisements & 9 & 38 & 9 & 56 & & 28.28 \\
\hline & Charging the Plastic Bags & 1 & 36 & 1 & 38 & & 19.19 \\
\hline & Complaints about E-Store & - & 29 & 5 & 34 & & 17.17 \\
\hline & Environmental Problems & 7 & 6 & 6 & 19 & & 9.60 \\
\hline & Other & 14 & 21 & 16 & 51 & & 25.76 \\
\hline & Total & 31 & 130 & 37 & & 198 & \\
\hline Total & & 262 & 473 & 185 & & 921 & \\
\hline
\end{tabular}

The distribution of the answers that consumers expressed to give against their negative experiences is given in Table 3. When the table is considered in terms of consumer reactions, approximately $90 \%$ of the consumers will boycott the store or complain to the institution, or a private or public institution in the following process. The boycott reaction has the highest rate $(54.93 \%)$ of the total responses. The reaction to the company, or the private or public institutions follows the boycott at a rate of approximately 35\%. However, the decision of the consumers to boycott is mostly because of the products of the discount stores and the attitudes and behaviours of the store staff. The complaints to the institution, or the private or public institutions are mainly because of the products of the discount stores as well as the problems that consumers face about returning the goods, and the price and payment.

On the other hand, when Table 3 is evaluated in terms of complaint categories, the reactions of the consumers in the process will mostly be about the products of the discount stores, often boycotting them and complaining to the institution, private or public institutions. Again, it is also seen that consumers will show their reactions to their complaints about personnel by boycotting the stores. 
ALANYA AKADEMİK BAKIŞ DERGİSİ 5/3 (2021)

Table 3: Frequencies of the future reactions of consumers by complaint categories

\begin{tabular}{|c|c|c|c|c|c|c|c|c|c|c|c|c|c|c|c|c|}
\hline \multirow{2}{*}{$\begin{array}{l}\text { Complaint } \\
\text { Categories }\end{array}$} & \multicolumn{4}{|c|}{ Boycott } & \multicolumn{4}{|c|}{ Complaint to the Environment } & \multicolumn{4}{|c|}{$\begin{array}{l}\text { Complaint to the Business or } \\
\text { Private or Public Institutions }\end{array}$} & \multicolumn{4}{|c|}{$\begin{array}{l}\text { Applying Legal Authorities for } \\
\text { Compensation }\end{array}$} \\
\hline & BIM & A101 & Sok & Total & BIM & A101 & Sok & Total & BIM & A101 & Sok & Total & BIM & A101 & Sok & Total \\
\hline Product & 17 & 22 & 9 & 48 & 2 & 3 & - & 5 & 7 & 16 & 1 & 24 & 1 & 6 & - & 7 \\
\hline Repair & - & - & - & - & - & - & - & - & - & 1 & - & 1 & - & - & - & - \\
\hline Return & - & 4 & 6 & 10 & - & - & - & - & - & 3 & 6 & 9 & - & 1 & - & 1 \\
\hline Atmosphere & - & - & - & - & - & - & 1 & 1 & - & - & - & - & - & - & - & - \\
\hline Personnel & 9 & 12 & 10 & 31 & - & 3 & 1 & 4 & 1 & 4 & 2 & 7 & - & - & - & - \\
\hline Service & 4 & 3 & - & 7 & - & - & - & - & 1 & 2 & 1 & 4 & - & - & - & - \\
\hline $\begin{array}{l}\text { Price \& } \\
\text { Pavment }\end{array}$ & 5 & 2 & - & 7 & - & - & - & - & 1 & 6 & 2 & 9 & - & - & - & - \\
\hline $\begin{array}{l}\text { Consumer- } \\
\text { oriented }\end{array}$ & - & - & - & - & - & 1 & - & 1 & - & - & - & - & - & - & - & - \\
\hline Other & 3 & 8 & 3 & 14 & 2 & - & - & 2 & 3 & 14 & 3 & 20 & - & 1 & - & 1 \\
\hline Total & 38 & 51 & 28 & 117 & 4 & 7 & 2 & 13 & 13 & 46 & 15 & 74 & 1 & 8 & - & 9 \\
\hline
\end{tabular}


The statistics on the use of photographs by the main categories of complaints of consumers are shown in Table 4 where it is seen that consumers mostly used photographs in complaints about the products of discount stores $(67.72 \%)$. When the complaints used in photographs were considered, it was seen that six out of every seven complaints used in the BIM store were related to the products. Just like in the BIM and A101 stores, the maximum use of photographs for the Sok belonged to the category of complaints about the products with $50 \%$. Another interesting finding in the table is that approximately $22 \%$ of the complaints that were made for the A101 store belonged to the bag prices and deceptive advertisement, etc.

Table 4: Use of photograph frequency by main complaint category

\begin{tabular}{cccccr}
\hline $\begin{array}{c}\text { Main Complaint } \\
\text { Category }\end{array}$ & BIM & A101 & Sok & $\boldsymbol{f}$ & \% \\
\hline \hline Product & 48 & 49 & 10 & 107 & 67.72 \\
Return & - & 3 & 1 & 4 & 2.53 \\
Personnel & 1 & 2 & - & 3 & 1.90 \\
Service & 2 & 2 & - & 4 & 2.53 \\
Price \& Payment & 2 & 8 & 2 & 12 & 7.59 \\
Consumer-oriented & 1 & - & - & 1 & 0.64 \\
Other & 2 & 18 & 7 & 27 & 17.09 \\
\hline Total & 56 & 82 & 20 & 158 & 100.00 \\
\hline
\end{tabular}

\section{CONCLUSION}

In the present study, the purpose was to determine the complaints and reactions of consumers about discount stores. The data consisted of the shares made by consumers in December 2018 at sikayetvar.com, which is one of the popular complaint forums of Turkey. The analysis of the data was made by using the manual Content Analysis Method, which is commonly used in text analysis in the context of Huefner and Hunt's (1992) categories of complaints from stores, and in the context of the CCB model of Day and Landon (1977), which is used commonly in text analysis and findings were presented.

\subsection{Theoretical/Administerial Recommendations And Limitations}

Theoretical implications of the study can be considered from three aspects: categorization of consumer complaints, consumer reactions and use of evidence. In terms of categorization of complaints results showed that discount stores' consumers often complain about the products of such retailers, supports findings of Blodgett and Anderson (2000). Besides finding of the present study, like Day and Ash's (1979) findings, is related with the dissatisfaction of consumers about the employees of discount stores. Another considerable finding of the study is that one out of every four consumers who complained about prices and payments stated that the price of the discount store was high. This result also supported Huefner and Hunt's (1992) findings. In the study, the complaints about bag fee in the "other" category are an important finding in terms of literature. Although plastic bags are offered to consumers for a fee in retail stores in many countries of Europe, the delivery of the bags for a fee in Turkey has been implemented since early 2019. The findings suggest that consumers are complaining about this situation although not at a high rate. The finding supports the finding of Liu and McClure arguing that consumer complaints are affected by culture (2001).

${ }^{1}$ This study is extended and revised version of the paper which was presented in the 6 . International Congress on Social, Human and Administrative Sciences. 
On the other hand, it is interesting that it was also determined in the present study that consumers complained very little about the atmosphere and quality of the services of the discount stores. Simple store design ( Steenkamp and Kumar, 2009) and employing fewer employees compared to their competitors (Bardakci and Baran, 2019) are some of the costreduction strategies of the discount stores (Steenkamp and Kumar, 2009) and these strategies reduce perceived quality of the service. However, the findings of the study showed that Turkish consumers do not complain too much these attributes of discount stores.

In developed markets, some authors (Lee et al, 2018) revealed that consumers mostly complain about payment, personnel and pricing of retailers, and others (Park, 2005) indicated that consumers often complained about products of retailers. However in current study, which conducted in a developing economy, founded that consumers often complained about the food as a product of discount stores. Moreover in service industry while consumers largely complained about personnel and refunding (Harris-Walker, 2001) the findings of the current study, which deals with discount stores as a type of general retailing, exhibited that consumers complaints vary by industry.

When the study findings were evaluated in the context of the consumer future reactions to discount stores, despite previous studies (Broadbridge and Marshall, 1995) found that consumers' furthest shares were with family and/or friends regarding dissatisfaction in the electrical goods retailer, in the present study, it was found that more than half of the consumers who expressed their reactions in the process would boycott the discount stores. Also, findings showed that approximately $35 \%$ of such consumers would transfer their dissatisfactions to the store, or to private or public institutions. Moreover, while findings of Makarem and Jae (2016) indicated that consumers boycott retailers due to their poor customer service or pricing, in this study, it was found that product, personnel and return are most important reasons in terms of the consumers' boycott to discount stores.

Findings of the study related to evidence usage supported the assertion of Simonson and Rosen (2015). Findings presented that one in every six consumers used photographs in complaints as proofs of their claims. Though this rate does not seem to be high, the value of the finding will be understood better when it is considered that every negative experience is not suitable for photographing.

This study also has very important consequences for companies. When it is considered that nearly $40 \%$ of the complaints were related with the products of discount stores, especially food, it becomes obvious that these companies, which produce products mainly to intermediary firms, should be more involved in the production. The attitudes and behaviours of the employees of the discount stores are one of the largely issues consumers complain. For this reason, stores should act more carefully in the selection and training of employees. In addition, although discount stores operate at low prices, consumers complain that the prices of these stores are high. Hence companies must convince consumers that the rising prices are because of the recent effective exchange rate increases. Another recommendation of the study for managers is about the deceptive advertisements of discount stores. Discount stores offer consumers surprise products on certain days (Kumar and Steenkamp, 2007). However, since these products come to the stores in a limited number, many consumers are unable to buy them, and thus, accuse discount stores of making deceptive advertisements. Informing consumers about this subject, for example, with a sign saying "in limited number", stores may prevent damage to their brands. 
It may be argued that the most important limitation of the study is that the data cover a specific period. Besides, the study dealt with only 3 stores in Turkey were covered in the study is another limitation. In future studies, researchers can focus on consumer complaints at different periods to determine if there are periodic differences in consumer complaints. This study was conducted in Turkey, which is a developing market researchers can focus on complaints of consumers about discount stores in underdeveloped or developed markets or on whether consumer complaints differ in different cultures. Finally, this study dealt with discount stores. Researchers can determine whether there are differences between the complaints of consumers in different types of retailers with studies that cover different types of retailers.

\section{REFERENCES}

AILAWADI, K. L., NESLIN, S. A., \& GEDENK, K. (2001). "Pursuing the value-conscious consumer: store brands versus national brand promotions". Journal of Marketing, 65(1), 71-89.

ANT, O., \& HACAOĞLU, S. (2018). “Turkish Economy Outperformed China, India in 2017”, https://www.bloombergquint.com/global-economics/turkey-s-economy-expands-7-4percent-last-year-on-consumption. (e.t. 30.04.2018)

ARMSTRONG, C., KULCZYNSKI, A., \& BRENNAN, S. (2021). "Cue the complaint: the visual cues of Facebook business pages and their influence on consumer complaint behaviour". Journal of Marketing Management, 1-31.

BALAJI, M. S., KHONG, K. W., \& CHONG, A. Y. L. (2016). "Determinants of negative word-of-mouth communication using social networking sites". Information \& Management, 53(4), 528-540.

BARAN, T. (2019). İndirim mağazalarından alışveriş yapanların özel markaya karşı tutumunda algılanan risk ve kalitenin rolü. Basılmamış Doktora Tezi. Pamukkale Üniversitesi Sosyal Bilimler Enstitüsü.

BARAN, T. (2021a). "Tüketicilerin İndirim Mağazalarına Karşı Tutumlarına Yönelik Bir Yapısal Model Önerisi”. İşletme Araştırmaları Dergisi, 13(2), 1632-1646.

BARAN, T. (2021b). "COVID effect on retailing: a study on consumers' retailer preferences during economic recession periods: evidence from Turkey as a predominantly Muslim society". Journal of Islamic Marketing. Inpress

BARDAKCI, A. \& BARAN, T. (2019). "İndirim mağazalarinin maliyet düşürme stratejileri ve Türkiye'deki perakendecilerin verimliliklerinin karşılaştırılması”. Pazarlama Teorisi ve Uygulamaları Dergisi, 5 (1), 37-67.

BEARDEN, W. O., \& TEEL, J. E. (1983). "Selected determinants of consumer satisfaction and complaint reports". Journal of marketing Research, 20(1), 21-28.

BLODGETT, J. G., \& ANDERSON, R. D. (2000). “A Bayesian network model of the consumer complaint process". Journal of Service Research, 2(4), 321-338.

BLODGETT, J. G., BAKIR, A., MATTILA, A. S., TRUJILlO, A., QUINTANILLA, C., \& ELMADA $\breve{G}$, A. B. (2018). "Cross-national differences in complaint behavior: cultural or situational?". Journal of Services Marketing, 32(7), 913-924.

BLODGETT, J. G., WAKEFIELD, K. L., \& BARNES, J. H. (1995). "The effects of customer service on consumer complaining behavior". Journal of services Marketing, 9(4), 3142.

BOOTE, J. (1998). “Towards a comprehensive taxonomy and model of consumer complaining behaviour". Journal of Consumer Satisfaction, Dissatisfaction and Complaining Behavior, 11, 140-151. 
BROADBRIDGE, A., \& MARSHALL, J. (1995). "Consumer complaint behaviour: the case of electrical goods". International Journal of Retail \& Distribution Management. 23(9), 8-18.

CHEBAT, J. C., DAVIDOW, M., \& CODJOVI, I. (2005). "Silent voices: why some dissatisfied consumers fail to complain". Journal of Service Research, 7(4), 328-342.

CHOWDHURY, S. K., SALAM, M., \& HASAN, M. (2014). "Antecedents and Consequences of Customer Satisfaction: An Empirical Study on Retail Store in Bangladesh". Stamford Journal of Business Studies, 6(1).

DAY, R. L. (1984). Modeling choices among alternative responses to dissatisfaction. ACR North American Advances.

DAY, R. L., \& ASH, S. B. (1979). Consumer response to dissatisfaction with durable products. ACR North American Advances. 438-444

DAY, R. L., \& LANDON, E. L. (1977). "Toward a theory of consumer complaining behavior”. Consumer and industrial buying behavior, 95, 425-437.

DRENNAN, A. (2011). Consumer study: $88 \%$ less likely to buy from companies who ignore complaints in social media. Retrieved August, 4, 2013.

DURIAU, V.J., REGER, R.K. \& PFARRER, M.D. (2007), “A content analysis of the content analysis literature in organization studies: research themes, data sources, and methodological refinements", Organizational Research Methods, 10(1), 5-34.

GARÍN-MUÑOZ, T., PÉREZ-AMARAL, T., GIJÓN, C., \& LÓPEZ, R. (2016). "Consumer complaint behaviour in telecommunications: The case of mobile phone users in Spain". Telecommunications Policy, 40(8), 804-820.

GAUR, A., \& KUMAR, M. (2018). "A systematic approach to conducting review studies: An assessment of content analysis in 25 years of IB research". Journal of World Business. 53, 280-289.

GOLDENBERG, J., LIBAI, B., \& MULLER, E. (2001). "Talk of the network: A complex systems look at the underlying process of word-of-mouth". Marketing letters, 12(3), 211-223.

GRÉGOIRE, Y., SALLE, A., \& TRIPP, T. M. (2015). "Managing social media crises with your customers: The good, the bad, and the ugly". Business Horizons, 58(2), 173-182.

HARRISON-WALKER, L. J. (2001). "E-complaining: a content analysis of an Internet complaint forum". Journal of Services marketing. Vol. 15, No. 5, pp. 397-412.

HEUNG, V. C., \& LAM, T. (2003). "Customer complaint behaviour towards hotel restaurant services". International Journal of Contemporary Hospitality Management, 15(5), 283-289.

https://www.perakendekulis.com/2018/02/zincir-marketlerin-magaza-saylar.html.

(e.t. 30.04.2018).

https://www.pwc.com/gx/en/world-2050/assets/pwc-world-in-2050-slide-pack-feb-2017.pdf (e.t. 30.04.2018)

https://www.twentify.com/tr/blog/sekt\%C3\%B6rlerin-iron-mani-i\%CC\%87ndirimmarketlerde-t\%C3\%BCketici-tercihleri. (e.t. 30.04.2018).

HUANG, M. C. J., WU, H. C., CHUANG, S. C., \& LIN, W. H. (2014). "Who gets to decide your complaint intentions? The influence of other companions on reaction to service failures". International Journal of Hospitality Management, 37, 180-189

HUEFNER, J. C., \& HUNT, H. K. (1992). "Brand and store avoidance: the behavioral expression of dissatisfaction". Journal of Consumer Satisfaction, Dissatisfaction and Complaining Behavior, 5, 228-232. 
ISTANBULLUOGLU, D., LEEK, S., \& SZMIGIN, I.T. (2017). "Beyond exit and voice: developing an integrated taxonomy of consumer complaining behaviour". European Journal of Marketng 51 (5/6), 1109-1128.

JACOBSEN, R., PARKER, G., JENSEN, T., MAGNUS, J., GOTTSTEIN, H., HEPP M. \& URDA, B. (2017). https://www.bcg.com/publications/2017/retail-consumerproducts-how-discounters-are-remaking-the-grocery-industry.aspx. (e.t. 30.04.2018).

JUHL, H. J., ESBJERG, L., GRUNERT, K. G., BECH-LARSEN, T., \& BRUNSØ, K. (2006). "The fight between store brands and national brands-What's the score?". Journal of Retailing and Consumer Services, 13(5), 331-338.

KAHN, B. (1998), "Dynamic Relationships with Customers: High-Variety Strategies", Journal of The Academy of Marketing Science, Vol. 26, No.1, pp. 45-53.

KHAN, M. S., KADIROV, D., BARDAKCI, A., IFTIKHAR, R., BARAN, T., KANTAR, M., \& MADAK, N. (2019). "Social media analysis of anti-consumption in Turkey". British Food Journal. 121(1), pp. 22-34.

KIM, C., KIM, S., IM, S., \& SHIN, C. (2003). "The effect of attitude and perception on consumer complaint intentions". Journal of consumer marketing. Vol. 20, No. 4, pp. 352-371.

KIM, W. G., LIM, H., \& BRYMER, R. A. (2015). "The effectiveness of managing social media on hotel performance”. International Journal of Hospitality Management, 44, 165-171.

KOTLER, P. (1973). “Atmospherics as a marketing tool”. Journal of Retailing, 49(4), 48-64.

KRIPPENDORF, K. (2004). Content analysis: An introduction to its methodology. Thousand Oaks, California: Sage.

KUMAR, N., \& STEENKAMP, J.B.E.M., (2007). Private label strategy: How to meet the store brand challenge. Harvard Business School Press, Boston, Massachusetts.

LEE, L. W., DABIRIAN, A., MCCARTHY, I. P., \& KIETZMANN, J. (2020). "Making sense of text: artificial intelligence-enabled content analysis". European Journal of Marketing. 54(3), 615-644.

LEE, A., \& LEE, J. H. (2020). “A Qualitative Study on Consumer Complaint Behavior Based on Cross Cultural Differences-Focusing on the Formation Process of Complaint Behavior by Korea and British Millennial Consumers". Fashion \& Textile Research Journal, 22(3), 335-348.

LEE, S., PARK, J., HYUN, H., BACK, S., BRYAN LEE, S., GUNN, F., \& AHN, J. (2018). "Seasonality of consumers' third-party online complaining behavior". Social Behavior and Personality: an international journal, 46(3), 459-470.

LEVY, M., \& WEITZ, B. (2012). Retailing Management. New York: McGraw Hill.

LIM, J., PARK, M., ANITSAL, S., ANITSAL, M. M., \& ANITSAL, I. (2019). "Retail customer sentiment analysis: customers'reviews of top ten us retailers'performance". Global Journal of Management and Marketing, 3(1), 124-150.

LIU, R. R., \& MCCLURE, P. (2001). "Recognizing cross-cultural differences in consumer complaint behavior and intentions: an empirical examination". Journal of consumer marketing, 18(1), 54-75.

MAJOR, M. (2018), “Consumers Rate Top Retailers: In What Do They Trust?” Winsight Grocery Business, Winsight Grocery Business, https://www.winsightgrocerybusiness.com/retailers/consumers-rate-top-retailerswhat-do-they-trust, accessed date, 16.05.2020.

MAKAREM, S. C., \& JAE, H. (2016). "Consumer boycott behavior: An exploratory analysis of twitter feeds". Journal of consumer affairs, 50(1), 193-223. 
MATTILA, A. S., \& WIRTZ, J. (2004). "Consumer complaining to firms: the determinants of channel choice". Journal of Services Marketing, 18(2), 147-155.

NEUENDORF, K. A. (2002). The content analysis: Guidebook. Thousand Oaks: Sage Publications.

NIELSEN, A. (2015). Global trust in advertising.

OREL, F. D., \& KARA, A. (2014). "Supermarket self-checkout service quality, customer satisfaction, and loyalty: Empirical evidence from an emerging market”. Journal of Retailing and Consumer Services, 21(2), 118-129.

PARK, C. (2005). "Complaints of Asian shoppers toward global retailer: a content analysis of e-complaining to Carrefour Korea". Asia Pacific Journal of Marketing and Logistics, 17(3), 25-39.

PILNY, A., MCANINCH, K., SLONE, A., \& MOORE, K. (2019). "Using Supervised Machine Learning in Automated Content Analysis: An Example Using Relational Uncertainty". Communication Methods and Measures, 13(4), 287-304.

PODNAR, K., \& JAVERNIK, P. (2012). "The effect of word of mouth on consumers' attitudes toward products and their purchase probability". Journal of promotion management, 18(2), 145-168.

POTTER, W. J., \& LEVINE-DONNERSTEIN, D. (1999). "Rethinking validity and reliability in content analysis". Journal of Applied Communication Research, 27(3), 258-284.

QUELCH, J. A., \& HARDING, D. (1996), "Brands versus private labels-fighting to win", Harvard Business Review, January-February, 99-109

RO, H. (2015). "Customer dissatisfaction responses to restaurant service failures: Insights into noncomplainers from a relational perspective". Journal of Hospitality Marketing \& Management, 24(4), 435-456.

RYANS, A. (2009), Lider Markalar ve Düşük Fiyat Rekabeti, Ümit Şensoy (çev), Türkiye İş Bankası Yayınları

SAMPAIO, C. A., HERNÁNDEZ-MOGOLlÓN, J. M., \& RODRIGUES, R. G. (2018). "Assessing the relationship between market orientation and business performance in the hotel industry-the mediating role of service quality". Journal of Knowledge Management.

SHORT, J. C., \& PALMER, T. B. (2008). "The application of DICTION to content analysis research in strategic management". Organizational Research Methods, 11(4), 727752.

SIMONSON, I., \& ROSEN, E. (2014). Absolute value: What really influences customers in the age of (nearly) perfect information.

SINGH, J. (1988). "Consumer complaint intentions and behavior: definitional and taxonomical issues". The journal of Marketing, 93-107.

STEENKAMP, J. B. E., \& KUMAR, N. (2009). "Don't be undersold!”. Harvard Business Review, 87(12), 90.

SUOMI, K., \& JÄRVINEN, R. (2018). "European Consumer Complaint Behaviour in the Financial Sector". Journal of Research for Consumers, (33), 38-82.

WANG, S., \& ALEXANDER, P. (2018). "The factors of consumer confidence recovery after scandals in food supply chain safety". Asia Pacific Journal of Marketing and Logistics, 30(5), 1379-1400. 